\title{
The Ethnography os Diocesan Visitations: A Source in the Study of Population, Family and Mestizaje in the Modern Period
}

\author{
Rangel Cerceau Netto \\ Department of History, Centro Universitário de Belo Horizonte, Belo Horizonte, Brazil
}

Email address:

cerceaup@gmail.com

To cite this article:

Rangel Cerceau Netto. The Ethnography os Diocesan Visitations: A Source in the Study of Population, Family and Mestizaje in the Modern Period. History Research. Vol. 6, No. 1, 2018, pp. 1-14. doi: 10.11648/j.history.20180601.11

Received: May 14, 2018; Accepted: June 8, 2018; Published: July 5, 2018

\begin{abstract}
The article seeks to analyze the diocesan visitations and how operated the ecclesiastical devassas and pastoral until the late eighteenth century in Portuguese America. It proposes to demonstrate how that documentation was part of the process of moralization and Westernization that formed the bureaucracy of American societies. From the critical historiography of this documental typology, the analysis brings into focus both the question of social groups' otherness, as the importance of these records for the study of family and mestizaje in the formation of diverse population.
\end{abstract}

Keywords: Episcopal Visits, Diocesan Visits, "Devassas" Ecclesiastical, Pastoral

\section{Introduction}

The planetary and demographic impact caused by the slave trade, the forced displacement of people to the New World and the dynamics of mestizos of such heterogeneous people were the most visible reflections of the globalization that inserted America, especially the mining regions of the Brazil, in the world context. In Minas Gerais, in the eighteenth century, the mixtures between native Indians, enslaved Africans and European colonizers built a society of intense modifications in which shocks, potentialities and contradictions marked a world that could be considered paradise and hell at the same time.

From the conception of "New World" the dynamics of mixtures were inserted in the perspective of transit, mobility and exchanges between people, goods and knowledge from different regions of the planet. Cultural and material practices were applied, based on control by means of manuscript records and not from the cultural traditions of the first natives of this continent. In this context, the bureaucracy was intensified and a large documentary mass was being built to give science of the reality lived. Thus, several documentary typologies of the colonial administration described the presence of different and mestizo social groups from different regions of Africa, Europe and America itself.

\section{The Church and Episcopal Visits: Records of a Long Tradition}

The Church, as a constituent part of the colonial state, registered its own actions as an institution. The custom of registering, through documents, the most different daily acts became part of reality as a culture bequeathed by Europeans. Thus, norms were imposed to ensure institutional control over society. Ancient methods and techniques of the long tradition of the Roman Church guided the construction of these records. Thus the standardization of ecclesiastical obligations became widespread. Bishops and vicars in charge of canonical visits should verify the maintenance of parish books and the very action of their subordinates in relation to the community. To this end, they instituted a method of surveillance managed by the Higher Clergy that eventually produced a kind of documentation of self-control, the socalled diocesan visits. It is on the documentation of this selfregulating method that we will make some considerations, the main objectives of which will be to understand this source and seek the traces of the family and the processes of miscegenation of the population in the colonial period.

In the early years of the eighteenth century, the villages and campuses of the region that later became the captaincy of 
Minas Gerais were constantly supervised by the bishops, who had the prerogative to visit the parishes. The aim was to care for the Lesser Clergy and the parishioners, in order to maintain spiritual and temporal vigilance. In this context, family relations was the focus of evangelization. To each settlement erected in this region, it was sought to preserve at all costs the evangelizing principle that marked the defense of the Catholic faith in the Iberian expansion after the reform implemented by the Council of Trent (1545-1563).

In most Portuguese cities around the Atlantic or within the regions bathed by this ocean sea, like Minas Gerais, ecclesiastical action was intended to build the Church and to indoctrinate the clergy and the population against those considered idolatrous and transgressors. In this perspective, it was sought to banish abuses, vices and scandals that could corrupt Christian morality. In general, securing a space of influence for Christianity in new areas of expansion as America was a strategy of the Catholic Church in dispute with other religions.

Religious disputes in the modern period have fostered various kinds of intolerance of traditions and beliefs. Thus, known religious customs that differed from the Catholic interpretation, as well as those customs alien to ecclesiastical doctrine, were repressed. Many people were considered apostate, heretics, like Jews, Moors and idolaters becoming also the focus of possible inquisitorial persecutions [1].

The itinerant actions of bishops, or persons delegated by them, on visits to the parishes produced large numbers of records. These actions were called diocesan or episcopal visits and produced the pastoral letters and the ecclesiastical devassas. The construction of these documentary typologies is part of a method created in the Middle Ages, which reminds us of Le Goff's reflections on the structures of the Modern State and the way of recording American preindustrial societies, for in the modern period the state still prevailed in the medieval tradition [2]. In this perspective, the devasas, the pastoral letters, as well as the role of relief, and the baptismal, marriages, deaths, inventory post-mortem inventories are reflections of an institutional project of Christianization of the world, inserted in a long duration and reworked and applied by Latin states in the most distant areas of the planet.

In Portuguese America, since the colonial period, civil and religious justice were put together by the institute of the patronage created in 1536. Often, the jurisdictional appeal of ecclesiastical judgment extrapolated the spiritual causes of faith and went to customs. Punishment for public crimes usually followed the mixed forum and belonged to both ecclesiastical and secular jurisdiction. In fact the two instances were complementary and the first was mentioned would be the owner of the action. Mixed court cases involved the marriage contract, such as dowry, food, filing, and indemnification for failure to honor the promise of marriage. Also, homicide, abortion, adultery, concubinage, alcouce, incest, witchcraft, sacrilege, blasphemy, perjury, usury, simony and tabolage. To the tribunal of the Holy Office were reserved the judgments of the crimes of heretical character and some sexual deviations as the sodomy, bigamy and the requests made by the priests in the confessionals, however, those cases, when occurred in Portuguese America were sent to Portugal. It is known that in Brazil, the tribunal of the Holy Inquisition did not act directly, but indirectly through ecclesiastical justice and its operators as archbishops, bishops and commissioners. Created in 1536 in Portugal, the Santo Oficio Tribunal was not established in Portuguese America and only visited Brazil twice, the first between 1591 and 1595 in Bahia and the second in Grão-Pará between 1763 and 1769.

The ecclesiastical courts' functioning systems in the Spanish and Portuguese Americas resembled, for example, the ecclesiastical tribunals in colonial Mexico acted at the diocesan level in addition to the secular judgment and also to the Holy Office in the time of Philip II. Traslosheros [3] demonstrates that in many cases involving the political regulation of the colonial organization of the Metropolis and the Vice Kingdom of New Spain was attributed to ecclesiastical justice, to link the moral aspects to a Christian universalist culture in social life. Thus it is possible to understand how different popular customs integrated into the legal universe that proposed a globalizing Christianity.

Specifically, the records of ecclesiastical devas are rich sources of information that allow us to trace a panorama of colonial everyday life through the details of the so-called "crimes of customs", that is, of the sins committed by the population according to the Tridentine Church. These documents were drawn up with the intention of imputing sentences to people who lived in disagreement with Catholic morality. They had an inquiring nature, in order to warn and punish the "deviants of the faith". They are, therefore, an excellent source for the study of social history and culture, since they allow us to visualize the daily behavior of the population in matters not only religious but of a moral nature. In the analysis of this documentation, it is possible to apprehend questions concerning the family life of the social groups regarding love, affection and sexuality.

It should be remembered that the production of these registers is disseminated by the places of influence of the Latin culture, not purely regional practices. In fact, the presence of records of episcopal visits in various regions of the world shows that the forms of production of this documentation had global amplitudes, at least in the regions that had the effective influence of Catholicism. They were embedded in the imperialist logic of the Roman Catholic Church, marked by papal edicts, and their projection may be summed up by the expression Urbi et Orbi (to the city of Rome and to the world), a blessing granted by the pope on special occasions.

In the Modern period, the planetary ambitions of the Catholic monarchies, due to the Iberian union between Portugal and Spain (1580-1640), began a political process of westernization [4] capable of promoting a constant transit of knowledge, people and products in possessions from beyond the sea. Under the aegis Felipe II of Spain (or Felipe I of Portugal), control forms were designed by means of registries 
in the American continent. The oral tradition of the natives of the region, which was convened to call Portuguese America, was soon replaced by the imposition of writing and norms of control through documents. In the case of Portuguese America, European mental structures bequeathed bureaucratic practices that produced a huge documentary mass. The application of control methods, of which the devas are part, are examples of the European mental structure of producing records and controlling the daily lives of the populations. In this research, we seek to analyze the bureaucracy produced by the religious apparatus, specifically, to the ecclesiastical devasas or diocesan visits, the documentation base of this work and on which we will make some considerations.

\section{Differences Between Diocesan and Holy Office Tribunals in Moralizing Politics}

The procedures that gave rise to the diocesan visits had medieval traditions and also formed the basis of the European Inquisition since the Council of Verona (1184). For Figueiredo [5] the devassas was a small Inquisition performed at the diocesan level, but in practice they had some distinctions. The devasas presented a simpler procedure in relation to the visits of the Holy Office and had a reduced amplitude in the application of penalties and deviations investigated.

It is worth remembering that the Inquiries made by the Holy Office sought to relate capital sins, heresies and other "deviations" due to a sexuality supposedly "deviant" and related to a demonic influence. The Episcopal visits, which produced the devassas and the pastoral letters, sought an evangelization from some sacraments, among which, and the principal marriage. In this sense, the visits of the Holy Office and diocesan visits reflect different areas and levels of performance. Hardly would the persons related to the concubinage reach the Inquisition Tribunal, except in a residual way and related to other "crimes" that the inquirers considered more serious. The same can be said of the debaucheries, which reflect residentially the crimes related to "deviant" sexuality in comparison to those related to the family. Perhaps this helps explain the difference of studies based on the inquisitorial sources of the Holy Office with those based on the structure of the devassas. Thus, studies that have as a documentary basis the records of the Court of the Holy Office pose the problem of moralizing of customs from sexuality [6] and those who rely on records of debauchery from the family [7]. In a way, this can be seen if we compare the "crimes" reported in the episcopal devassas occurred in Minas Gerais with the "crimes" observed in the visits of the Holy Office in Bahia, in the Grão Pará and in the Portuguese Inquisitorial Courts.

Usually, the devassas constituted a first stage for a possible inquisitorial process. In this direction, the argument that the actions of the Inquisition are linked to diocesan visits. Most of the bishops were also commissioners of the Holy Office. In this sense, in the Minas Gerais of the eighteenth century, the presence of the Inquisition was not justified, since the prelate of the region was in charge of regulating customs. To support this position Boschi [8] demonstrated how various cases of bigamy, reprimanded at the diocesan level, were referred to the Inquisition in Portugal. However, the author saw in the great number of devasas the argument of the effectiveness of Portuguese colonial policy for the institutional success of the state and of the Church in the region of Minas Gerais. Our argument tends to qualify the reading of Boschi. In our view, the great number of devassas throughout the eighteenth century demonstrates the very opposite, that is, the population repeatedly practiced strange customs or even attributed other meanings to Catholic doctrine, which caused them the reprimand that the bishops tried to impose.

Vasconcelos, one of the earliest historians working with this type of documentation in Brazil, demonstrates that the attempt to moralize popular customs on the part of the Church was not successful. Analyzing 50 books on the devasas, the author agrees that the ecclesiastical action by the moralization of the customs had a negative conclusion, at least in Century XVIII [9]. The Tridentine Church failed to impose its doctrine, for it bumped into the customs of the varied population. In this view, the devasas demonstrate that laws without custom, like customs without doctrine, ended up compromising the effectiveness of this policy that was partially extinguished in the early nineteenth century.

In another perspective of analysis are those works that were used of the devassas to justify the historical discourse of the civilizing process [10]. Usually, these approaches tend to reaffirm the moralizing logic of these sources. The acceptance that the customs were corrupted ends up justifying the Portuguese cultural imposition on other social groups [11]. Or even to accept, a priori, a process of Westernization or domination without its due historicity with conflicts, exchanges and sociocultural influences seems to us fearful. In this perspective, it is difficult to recover the plurality and participation of the social groups that have made colonial society viable with its various contradictions. The discourse present in many of these colonial sources produced by civil and religious administration does not take into account mores and heterogeneous sociocultural practices.

Souza, in self-criticism to one of his reference works, emphasizes the need to relativize in the sources the overwhelming weight of official discourse. The author, using great measures of the ecclesiastical devastate, reaffirmed the need to read the testimonies contained in these documents in reverse. After all, many of his conceptions, defended in the first edition of disqualified gold, were based on the ordinary logic of the sources, which eventually betrayed him [12].

In Minas Gerais, in the eighteenth century, the constant influx of migratory flows, mainly Portuguese and African, integrated with the presence of indigenous and mestizos of all kinds, provided the enabling environment for differences 
and estrangement to take place within the framework of family relations. Boschi's argument becomes more effective in the nineteenth century, in which the moralization implemented by the Catholic Church during the previous three centuries will crystallize. All this is associated with a new migratory impulse of Europeans.

However, the form of execution of diocesan visits and the Holy Office resembled one another. The search for a "truth" based on Catholic principles led to the production of this documentary typology. The bishops, through strategies of catechization and evangelization marked by psychological, physical and financial pressures, imposed a Christian culture based on the Tridentine presuppositions. The actions of ecclesiastics in the visits began with the application of the Regiment of the Ecclesiastical Auditorium (1720), contained in the First Constitutions of the Archbishopric of Bahia (1719), which was an edict with 40 questions that aimed to filter the reports of the complainants and reported, adjusting them to their moral stereotypes. That is, the bishops or inquisitors did a rereading of the daily life, in order to implement the desirable codes of conduct through reprimands. Certainly, a culture practiced by the Portuguese and enforced for four centuries by the constituted powers had some effect on the various social groups that composed the mixture of the social web of Portuguese America.

Table 1. Edital of questions asked by the visitors to the population, books of denunciations

\begin{tabular}{|c|c|c|c|c|c|}
\hline Questions that motivated complaints & $\begin{array}{l}\text { Episcopal visits } \\
1737-1738\end{array}$ & $\begin{array}{l}\text { Episcopal visits } \\
1748-1749\end{array}$ & $\begin{array}{l}\text { Episcopal visits } \\
1759-1760\end{array}$ & $\begin{array}{l}\text { Episcopal visits } \\
1767-1778\end{array}$ & Total \\
\hline $\begin{array}{l}1^{\circ} \text { If you know or have heard of any person committing the very } \\
\text { grave crime of heresy, or apostasy having, believing, saying or } \\
\text { doing anything against our Holy Catholic Faith in any, or any article } \\
\text { of it, even if it is not infamous; }\end{array}$ & 10 & 1 & 2 & 0 & 13 \\
\hline $\begin{array}{l}2^{\circ} \text { If any person has or reads books of heretics, or any other } \\
\text { unlicensed closures of the Apostolic See, or of the persons, who can } \\
\text { do so; }\end{array}$ & 0 & 00 & 0 & 0 & 0 \\
\hline $\begin{array}{l}3^{\circ} \text { And if they know or have heard that somebody said any } \\
\text { blasphemy against the honor of God, of the Virgin Our Lady or his } \\
\text { Saints, saying some words injurious or that do not agree to God and } \\
\text { his Saints; }\end{array}$ & 0 & 0 & 0 & 0 & 0 \\
\hline $\begin{array}{l}4^{\circ} \text { If they know that a person is a sorcerer, spells or use them to do } \\
\text { good or bad, to turn on or off, to know secret things or to guess or } \\
\text { to any other effect, or invoke the demons, or with them has an } \\
\text { express or tacit agreement, even if it is not infamous; }\end{array}$ & 2 & 0 & 40 & 20 & 62 \\
\hline $\begin{array}{l}5^{\circ} \text { If any person would come or bless or heal with words, or } \\
\text { blessings without our permission or from our caretaker, and if there } \\
\text { is anyone who will seek to believe, that with his blessings there } \\
\text { may be health; }\end{array}$ & 2 & 18 & 39 & 10 & 69 \\
\hline $\begin{array}{l}6^{\circ} \text { If any man is married to two living women or women with two } \\
\text { husbands, even if there is no fame; }\end{array}$ & 0 & 0 & 0 & 0 & 0 \\
\hline $\begin{array}{l}7^{\circ} \text { If some clerics of sacred orders, religious or religious professes } \\
\text { are married although there is no public fame of the case; }\end{array}$ & 8 & 0 & 0 & 0 & 8 \\
\hline $\begin{array}{l}8^{\circ} \text { If any Priest committed any woman in the act of confession or } \\
\text { disobliges her secrecy, even if it is not infamous. }\end{array}$ & 6 & 1 & 2 & 0 & 9 \\
\hline $\begin{array}{l}9^{\circ} \text { If any person has committed the crime of simony or selling or } \\
\text { buying benefits, or presenting them, or receiving money or } \\
\text { temporal things for administering sacraments, or other spiritual } \\
\text { thing or about it, makes illicit or reproved conventions or facts; }\end{array}$ & 0 & 0 & 3 & 0 & 3 \\
\hline $10^{\circ}$ If there is any person who puts violent hands on clerics or & & & & & \\
\hline $\begin{array}{l}\text { religious, or that in the Church or Adro of her wounded or injured } \\
\text { or beaten or by any other way committed sacrilege; } \\
11^{\circ} \text { If there be any person who swore false in Judgment, or is this }\end{array}$ & 0 & 3 & 2 & 0 & 5 \\
\hline $\begin{array}{l}\text { infamous or accustomed to swear falsely and scandalous oaths } \\
\text { outside the Judgment; }\end{array}$ & 7 & 6 & 35 & 3 & 51 \\
\hline $\begin{array}{l}12^{\circ} \text { If any person of the Alcouve at his house consenting or } \\
\text { inducing in them to give women to men and of that is infamous; }\end{array}$ & 10 & 14 & 62 & 4 & 90 \\
\hline $\begin{array}{l}13^{\circ} \text { If a man or a woman consent that her daughters make evil of } \\
\text { themselves or of the husband to his wife, and are of this infamous; }\end{array}$ & 10 & 2 & 39 & 1 & 52 \\
\hline $14^{\circ}$ If any person uses to vomit women or men and it is infamous; & 12 & 8 & 71 & 3 & 94 \\
\hline $15^{\circ}$ If any person has sinned evil or bestiality; & 1 & 1 & 7 & 0 & 9 \\
\hline $\begin{array}{l}16^{\circ} \text { If any person has committed the crime of incest, having } \\
\text { intercourse with a relative by consanguinity or affinity to a } \\
\text { forbidden degree or comadre com compadre, or godfather with } \\
\text { godson, or godmother with godson and there is public fame; }\end{array}$ & 21 & 30 & 24 & 3 & 78 \\
\hline $\begin{array}{l}17^{\circ} \text { If any ecclesiastical person, or secular, single or married, that } \\
\text { are amancebados with scandal and of that there is fame in the } \\
\text { parish, place, country or village or in the greater part of the }\end{array}$ & 517 & 445 & 682 & 54 & 1698 \\
\hline
\end{tabular}




\begin{tabular}{|c|c|c|c|c|c|}
\hline Questions that motivated complaints & $\begin{array}{l}\text { Episcopal visits } \\
1737-1738\end{array}$ & $\begin{array}{l}\text { Episcopal visits } \\
1748-1749\end{array}$ & $\begin{array}{l}\text { Episcopal visits } \\
1759-1760\end{array}$ & $\begin{array}{l}\text { Episcopal visits } \\
1767-1778\end{array}$ & Total \\
\hline \multicolumn{6}{|l|}{ neighborhood and street; } \\
\hline $\begin{array}{l}18^{\circ} \text { If there are any ecclesiastical or secular who has in his house } \\
\text { some woman of whom there is scandal or suspicion in the } \\
\text { neighborhood; }\end{array}$ & 13 & 0 & 4 & 0 & 17 \\
\hline $\begin{array}{l}19^{\circ} \text { If there are any married women who badly scandal their women } \\
\text { or live apart without just cause; }\end{array}$ & 14 & 59 & 146 & 22 & 241 \\
\hline $\begin{array}{l}20^{\circ} \text { If there is any person who is an eleven, giving money, bread } \\
\text { and wine, olive oil or other such things borrowed to receive more } \\
\text { than the principal lot, or see merchandize for more than worth, with } \\
\text { the money in hand of the price strictly for waiting reason; or } \\
\text { purchase them for less than the very small thing, for giving money } \\
\text { beforehand, and of the so-called public fame; }\end{array}$ & 6 & 1 & 10 & 2 & 19 \\
\hline $\begin{array}{l}21^{\circ} \text { If there is any person who gives rent beasts or oxen or cows } \\
\text { with a condition or a covenant to die, they do not fail to pay their } \\
\text { rent; }\end{array}$ & 1 & 0 & 0 & 0 & 1 \\
\hline $22^{\circ}$ If there is someone person or people are in hatred with scandal;; & 3 & 12 & 41 & 6 & 62 \\
\hline $\begin{array}{l}23^{\circ} \text { If some are promised to marry and cohabit as if they were } \\
\text { received in the face of the Church; }\end{array}$ & 1 & 25 & 29 & 11 & 66 \\
\hline $\begin{array}{l}24^{\circ} \text { If any person is married in a forbidden degree without } \\
\text { legitimate dispensation; }\end{array}$ & 0 & 0 & 0 & 0 & 0 \\
\hline $\begin{array}{l}25^{\circ} \text { If any person who is accustomed to eating meat on forbidden } \\
\text { days without legitimate cause or license or is accustomed to not } \\
\text { hear Mass on the days of obligation or is this infamous; }\end{array}$ & 22 & 25 & 41 & 5 & 93 \\
\hline $\begin{array}{l}26^{\circ} \text { If there is any person obliged to say chapel mass or to perform } \\
\text { wills and did not do it and if the priests do not receive it from the } \\
\text { masses they exceed the number of a hundred as ordered to them; }\end{array}$ & 0 & 0 & 0 & 0 & 0 \\
\hline $\begin{array}{l}27^{\circ} \text { If any person dies because of the parish priest without } \\
\text { sacraments, although there is no fame of this; }\end{array}$ & 2 & 14 & 0 & 0 & 16 \\
\hline $\begin{array}{l}28^{\circ} \text { If the parson is negligent in administering the sacraments, or } \\
\text { administering them without money or anything that is worth it, and } \\
\text { even if he is accustomed, he does not want to administer it without } \\
\text { first giving it to him, even if he is not unfaithful, or if he does not } \\
\text { teach the doctrine as ordained by the Constitutions; }\end{array}$ & 18 & 20 & 0 & 0 & 38 \\
\hline $\begin{array}{l}29^{\circ} \text { If the parson is remiss and negligent in going to order the } \\
\text { deceased or did not want to do without first give him something, } \\
\text { even if there is no fame; }\end{array}$ & 2 & 11 & 0 & 1 & 14 \\
\hline $\begin{array}{l}30^{\circ} \text { If the parson harasses the customers or treats them poorly at the } \\
\text { station or otherwise fails to do his office as a dev, although there is } \\
\text { no fame; }\end{array}$ & 6 & 15 & 1 & 0 & 22 \\
\hline $\begin{array}{l}31^{\circ} \text { If a Clergyman is a trafficker, tenant or negotiator, he continues } \\
\text { the taverns, is accustomed to bring guns through town, village or } \\
\text { place or to walk in the habit of a layman or to visit, If he is taful } \\
\text { brigoso, revoltoso, does not pray the canonical hours and Either of } \\
\text { these things is infamous; }\end{array}$ & 8 & 0 & 2 & 0 & 10 \\
\hline $\begin{array}{l}32^{\circ} \text { If any cleric uses a suspicious woman, or any other } \\
\text { ecclesiastical or secular person, there is a person in the house of } \\
\text { scandal, or the ecclesiastical children at home who have been } \\
\text { clergymen. }\end{array}$ & 15 & 0 & 2 & 0 & 17 \\
\hline $\begin{array}{l}33^{\circ} \text { If there is any person who lets himself be excommunicated for a } \\
\text { year without asking for the benefit of acquittal; }\end{array}$ & 9 & 9 & 8 & 1 & 27 \\
\hline $\begin{array}{l}34^{\circ} \text { If there is any person who does not confess and communed in } \\
\text { the past Lent or is accustomed to work on Sundays and holy days; }\end{array}$ & 5 & 11 & 6 & 3 & 25 \\
\hline $\begin{array}{l}35^{\circ} \text { If there are some people who do not pay the Churches or the } \\
\text { Ministers of them the tithes premisses entirely as they are obliged; }\end{array}$ & 0 & 0 & 2 & 0 & 2 \\
\hline $\begin{array}{l}36^{\circ} \text { If there are some persons who give or lend or by any other } \\
\text { means property of the churches without the solemnities of which } \\
\text { the law requires, and our license or if there is any person who } \\
\text { would usurp the said goods without having it by right of request; }\end{array}$ & 0 & 0 & 9 & 10 & 10 \\
\hline $\begin{array}{l}37^{\circ} \text { If there is any house in which to throw with scandal or if of } \\
\text { tabolagens; }\end{array}$ & 0 & 0 & 0 & 0 & 0 \\
\hline $\begin{array}{l}38^{\circ} \text { If they know or have heard that any person intimidates } \\
\text { witnesses, that they come or are to come to visitation, that they } \\
\text { should not tell the truth, or after witnessing, that they would misuse } \\
\text { words and deeds; }\end{array}$ & 5 & 3 & 1 & 0 & 9 \\
\hline $\begin{array}{l}39^{\circ} \text { If they know that an ecclesiastical court official, Vicar General, } \\
\text { Visitor, Vicar of Rod, Promoter, Meirinho, clerks, notaries, }\end{array}$ & 19 & 0 & 3 & 0 & 22 \\
\hline
\end{tabular}




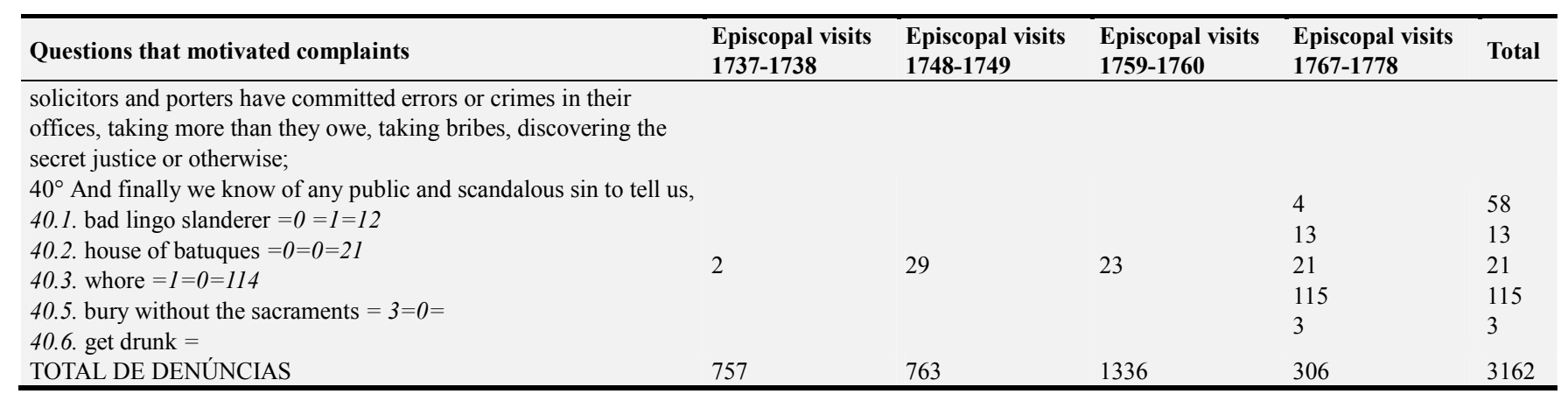

The data included in Table 1 make it possible to verify that, in the universe of 3,162 denunciations made by the population according to the interrogations applied by the visiting table, more than half (1698) referred to question 17 , which reflects the practice of simple concubinage and adulterin. In addition to questions 16, 18, 23, and 32, all relating to incestuous concubinage, clerical concubinage, and the promise of marriage, we have the surprising number of 1,876 complaints, accounting for nearly 60 percent of the total. But if we compare this number to question 6 , which represents bigamy, that is, to those people who have instituted more than one marriage with their still-living companions, we have no case in these four wastes. The same was true for question 24, which related to married persons who were not exempt by the degree of kinship. Taking these data as a reference, it can be inferred that for the already married individuals there was a valorization of the amancebamento, which may justify the option of many Portuguese and Brazilian natives, who migrated to the Rio de Velhas and Serro Frio Counties in Minas Gerais, helping to further relativize the justifications for non-marriage motives.

It is noted that, in some way, the practice of concubinage for the Catholic Church was an "evil to be extirpated." After all, socialization was the most practiced social custom and, consequently, the most contested by evangelizing policy, in order to impose a homogeneous family institution model based on Tridentine norms. The mere fact that there are numerous records of men and women guilty of living in concubinage in the records of the ecclesiastical debauchery already reflects the harsh reality of a large number of couples living outside the sacrament of matrimony. Also noteworthy are the 241 cases contained in question 19, which suggest a break in the marital relationship of married persons. This shows how difficult it was to establish a monogamous, indissoluble marriage.

Relating the data on concubinage, separated by the four wastes, it follows that up to the $1760 \mathrm{~s}$, the rates of mancebia remained unchanged at high rates. In the $1770 \mathrm{~s}$, with reference to the last wretchedness, numbers suddenly decline, which may justify abandoning the repressive politics of debauchery. This hypothesis becomes more plausible due to the almost inexistence of this ecclesiastical juridical procedure for the period after 1780. It is assumed that the Pombaline policies on the laicization of the State hit the ecclesiastical action in full and, consequently, the legal procedure of the devasas which was nothing more than an itinerant arm of episcopal justice. In this respect, it is believed that ecclesiastical politics underwent a significant change betting its cards on the moralization of the customs from the evangelization executed, almost exclusively, by the pastoral letters. In this way it is possible to deduce that the ecclesiastical policy, guided by the repressive action of the devasas, had little satisfactory results towards the moralization of the customs. It is worth noting that the hypothesis justifying the end of the debauchery, due to the mining crisis, does not hold for the Serro Frio, since the golden period of diamond exploration occurs precisely from the third quarter of the seven hundred. If such a policy were actually followed it was to be expected that the debaucheries would continue to occur for that region. In this case, it is possible to infer that for the period comprising the last quarter of the eighteenth century, the debaucheries also operated in the region of Rio das Mortes, which became a large center for agricultural supplies, mainly after the Viceroy of Brazil from Salvador to Rio de Janeiro in 1763. However, what is perceived is an abandonment of the repressive policy of the debauchery by the Church.

In a way, Table 1 reflects the attempt to implant the moralization of customs against some of the practices of cultural estrangement of the population present in the Minas Gerais of the XVIII century. From this moment, we will relate the practical application of the questions contained in the table presented with some cases found in the witness books. This task has the objective of demonstrating how the experience of the population operated against the agents of ecclesiastical moralization.

The question raised here refers to the question: to what extent have the political impositions of Tridentine doctrine been effective in transforming the family traditions of the various social groups present in the reality of Minas Gerais in the eighteenth century? To what extent has the continued practice of the devasas been able to transform the cultural realities of a very diverse population into their customs, especially in family relations? Certainly an exact answer to these questions will not be forthcoming, but a detailed analysis of this documentation can help us to qualify the cultural influence of Tridentine politics in the African, Indian, Portuguese, and diverse mestizo groups present in the reality of Portuguese America.

Ginzburg demonstrated how the methodology of inquisitors and anthropologists come together to unravel a certain universe of values that emerge in the face of 
inquisitorial testimony [13]. In this sense, the reading that the visiting priests made of the daily behaviors was close to the inquisitors and ended up reflecting the edict of questions applied by them. The visitors created categories to describe the empirical realities observed before the beliefs and values that were mixed in the diverse social groups present in the reality of Minas Gerais of century XVIII. The interpretation in the light of the Tridentine writings carried out by these diocesan authorities enabled them to create their own "truths", especially with regard to family relations. As Ginzburg observed in the study of the Italian Inquisition between the sixteenth and seventeenth centuries, the fertility agrarian cults practiced by the individuals had demonic interpretations, real battles of peasants and witches for the good of the harvest and the salvation of the soul [14]. In the inquisitors' conception, peasant descriptions reflected evidence of sabats, but in cultural terms, for anthropologists and historians, these traces were - and configure - as rich folk traditions that could be analyzed for new looks.

In the moralizing of family relations carried out by the bishops, the imposition of a "truth" that ended up bringing together the sacrament of monogamous and indissoluble marriage was opposed to an infinity of free relationships arising from various cultural practices and the intertwining between them. Many of these practices were characterized as family relations and were exercised among Africans, Portuguese, Indians and mestizos of varied identities. In the records of diocesan visits, most relationships that did not fit into marriage were reduced to the term concubinage, but also those associated the prostitution.

The classification of the various types of concubinates was built by the Tridentine Church code of conduct, which typified the persons involved in these "offenses" according to the possibility of reaching the condition of marriage. In this way, the Catholic Church, through the visitors, divided the "offending" population into several groups, according to the types of deviations related to so-called crimes against the family. In another analysis, these "crimes against the family" reflected other forms of complementary and unconventional family organizations to the unique pattern of perpetual monogamy advocated by religious agents. The family and the processes of mestiçagem that emerge from the analysis of this source is fruit of the contradictory dynamics between the Christian culture and the culture of the social agents. In this sense, it is marked by the instability of meanings attributed and reworked by the subjects of these relationships. Those involved in the same family relationship could have different understandings about it. The notion of family and mestizaje is understood as a living organism of transformations that integrate ethnic, social and cultural conflicts and differences, but to a certain extent did not constitute insurmountable obstacles to a necessary consent to the proper understanding of family.

The knowledge of the population about their family organizations was acquired as the tridentine ecclesiastical principles concerning marriage and concubinage were applied by the bishops and absorbed by the community. The observations showed how the notion of public scandal was applied by the religious in those relationships listed as concubinage. In a way, the Church, by associating the scandal with this type of relationship, has created a mechanism for the moralization of family relationships through marriage. Thus, by placing concubinage as a sin to be eliminated, the Church eventually condemned men and women who lived in other family organizations. This is what is seen in the lines of inquisitorial documents of an ecclesiastical forum, among which are the devasas. As the concubinage stood out among the moral crimes most practiced by the colonial population, it gained a prominent position in the classificatory scale of crimes against the family. Therefore, an in-depth study of the records of ecclesiastical failures reveals the way in which the visiting priests were guided to classify the concubinage offenses, according to the quality and condition of those involved and the circumstances of each case.

The inquisitorial nature of the record reveals the other side, that is, ecclesiastical visits and devasas demonstrates precisely the Church's need to affirm her dispositions and, consequently, to extirpate any kind of union that escapes the sacrament of matrimony. The ecclesiastical action itself, however, already showed the dimension that extramarital marriages and complementary to the Christian model acquired in the period. Thus the ecclesiastical devastation can represent the misrepresentation of the Church in relation to the daily practices.

The ambiguity of this type of record can be a trap in accepting the discourse of the visitors without question. For this reason, it is worth recourse to Farge's [15], for which the documents constitute the evidence of a fault, that is, the record is the indication of what was irretrievably lost and left only a signal of its passage. At the same time the document shows us traces of what has been lived and happened, which impels us to try to fill the symptom of this lack with plausibilities. Certainly this action helps us reduce our strangeness to the past and better understand the creation of a custom by imposing a religious political culture.

If, on the one hand, the "truth" of the crimes attributed by the religious is evident at all stages of the process, on the other hand, popular testimonies show an ambivalent universe that is even richer and more engaging in mixed cultural traditions. Certainly, for Chartier [16] the testimonies present in this type of documentation are representations of the actual operative tension of the society involved between its different subjects and social groups. In this sense, the "truths" or plausibilities would be more and more nuanced according to the social groups of those involved.

In this same conception of approach, Schwartz, studying the Iberian Atlantic world, demonstrates the ideas of tolerance and religious intolerance present in the discourses of ordinary people of the sixteenth, seventeenth and eighteenth centuries. For the author, cultures are in transformation and are capable of integrating conflicts and differences. For this reason, individuals within the same community could have diverse interpretations of religious 
discourses. Through institutional coercion in the vestiges of inquisitorial sources, Schwartz shows the instability of cultural meanings in various regions of the Iberian Atlantic, but increasingly relativized in social groups [17].

From this analysis arises a fruitful dialogue on the otherness of the groups that composed the cultural reality lived in regions that were articulated by the Portuguese, from the XVI century. The problem of otherness imposes a challenge on us: that of overcoming the monolithic vision that values or despises only the Portuguese and Christian influence, or rather, the European mental structure impregnated in these manuscripts. Thinking about these registers with the expectation of the relationship between the Portuguese and the various groups of indigenous people, Africans and those who have merged with them, and vice versa, enables us to advance our view of a dynamic universe of melds within the family. The lascivious stare launched by the visitors on the colonial populations emphasized the disqualifying discourse of the other. Thus, before a devastated, uncultured and disqualified population, derived from the stereotyped vision of the Portuguese visitors, there are individuals and social groups with intentionalities, cultures, influences and alternatives.

Resende [18] making use of the devassas, was one of the first to focus on the ethnic perspective related to the indigenous group. The author, questioning the action of the visiting priests, recovered the vision of alterity of the exiled Indians of their villages. The study of Resende is a good index to identify in these sources social groups increasingly more nuanced for the reality of Minas Gerais eighteenth century.

Although the devassas were official sources, it was hardly possible for the religious agents who constructed them to have a posteriori dimension of the polysemy of their use. Influenced by dogmas, they firmly believed that they were defending the one true faith. Perhaps they envisioned having the records to justify their acts and to be recognized in a posthumous temporality as shepherds of God and unconditional advocates of Catholic doctrine. However, historians are not naïve and the analysis of this source of research overcomes a strong external and internal criticism. Tolerance and freedom of conscience, so dear to our contemporaneity, helps us to inquire into a past in which not all could be saved in their creed or "in their law", to remember an important idea present in the testimonies of the thousands of processes inquisitorials of ordinary people.

If, on the one hand, the traces acquired by the devas retain voluntary acts of ethnocentrism and the imposition of a culture that was foreign even to those who practiced a less dogmatic Christianity. On the other hand, they also bequeathed to us traditions that were involuntary, not thought of within the log-building logic. All of this enables us to interpret these documents beyond the purpose of their creation and functionality.

The devassas or diocesan visits are considered sources of repression, which refers to a conflicting reality par excellence among its interlocutors. The dynamics of the contradictory, already present in these types of manuscripts, demonstrates the rich and complex dimension of this record. However, if on the one hand these documents reflect a character of dispute between criminals and victims, on the other, it constitutes a fragment in which we can travel to a reality beyond our own, of distinct and mixed cultural traditions.

The devassas constituted a specific juridical procedure of summary inquiry of witnesses made or delegated by the Ecclesiastical Court (bishop) to ascertain the crimes that, according to Catholic logic, affected daily life. In this sense, affective relationships that were not included in Catholic doctrine would suffer the legal penalties anticipated. In the First Constitutions of the Archbishopric of Bahia (1707), they were defined as inquiries in which an information of offense made by the authority was obtained. In the ecclesiastical legislation, the devassas had differences and specificities among themselves. According to the logic, they could be general or special, as described:

(...) the devasas to which the law called inquiries, are an information of crime, made by authority of the ex officio Judge. They were ordered so that there were no accused, the crimes were not punished: and these, either general or special. The general ones, or are totally, like those, in which one is generally inquired of the crimes, excesses and sins to be amended, and to punish, which are the ones that the prelates do when they visit their Dioceses; or are general as to the persons, and special, as to crimes and offenses, as it happens, when it appears that he committed some sacrilege, or serious crime, whose knowledge belongs to the ecclesiastical forum, and it is not known who committed it. Special inquiries or debaucheries are when you inquire especially about people, such as the crime, specifying the right people, and a certain crime. The general ones can be done, although there is no infamy, or indicia as any person, because they are made to know if there are guilts, or sins, that must be amended, or to punish or other things, that have to be reformed. [19]

The devassas, to which the law called inquiries, constitute an information of offense, made by authority of the ex officio judge. According to Lemos, the ex officio procedure was characterized by public outcry or the outcry of the victim. In this sense, one can see, in relation to the authority of the judge, that he could investigate any situation, whether public or not. What is clear from the reading of Lemos's [20] work is that civil or ecclesiastical devastation had the same basis of legal procedure. They differed only as to the nature of the crimes to be investigated. Thus, in civilian debaucheries, the crimes of riots, inconfidences, or some suspicion of acts that might threaten the Portuguese Crown were generally investigated, although in some situations civil cases involving deaths, fights, fires, rape, witchcraft, concubinage. Already in the ecclesiastical devas, it was sought to investigate the usual crimes against Christian morality, be they public or private.

Another important fact concerns the system of patronage, which was constituted in the administrative, legislative and legal regency exercised by the union of the civil state with 
the ecclesiastic, coexisting the two in a common purpose, but based and based on codes and laws of their own: Canon Law and its variations for the ecclesiastical state and the Civil Law and its unfolding for the civil state. Another fundamental point regarding the two spheres in which documentary production was made in the colonial period concerns the records of seats: baptisms (roughly, also, for the time, birth records), marriages and deaths were within the jurisdiction of the sphere ecclesiastical Other registries, such as wills and inventories, had a double forum, and it is possible to exist in both the civil and ecclesiastical spheres. Debauchery processes also had a mixed forum. Commonly, lawsuits involving customs offenses could be judged and judged in the two legal spheres.

In practice, the Church tried to control the daily behavior of the population. In this context of people and practices so different culturally appeared in the eyes of the visitors the practitioners of all kinds of deviation. Thus, in the eyes of the visitors, apostates, heretics, sorcerers, healers, benzeneers, gamblers, drunks, conspirators, judaizers, ants, whores, liars, charlatans, adulterers, pimps, solicitors, incestuous and, above all, concubines.

In practice, the devasas expressed the Catholic Church's attempt to control the daily behavior of the population. In this context of people and practices so different culturally appeared in the eyes of the visitors the practitioners of all kinds of deviation. Thus, in the eyes of the visitors, apostates, heretics, sorcerers, healers, benzeneers, gamblers, drunks, conspirators, judaizers, ants, whores, liars, charlatans, adulterers, pimps, solicitors, incestuous and, above all, concubines.

The difficult thing would not be to verify the amount of deviants present in the devasas, but to demonstrate the way in which the documentary logic reflects a mental construction of the visitors who are in disagreement with the subjects' experiences. In this sense, the documentary typology divided between the edict, the list of witnesses and the list of culprits reflect, on the one hand, a moralizing logic of Catholic cultural practice and, on the other hand, a misrepresentation of what would be the customs of part of the population.

\section{Devasas: A Complex Logic Between Edict, Witnesses and Guilty Parties}

In the case of the formation of an ecclesiastical devassa it was necessary to institute the table, composed by the visitor, meirinho and clerk, these duly sworn. The debauchery's visit usually began with the announcement to the community in which it would unfold. The reason for the warning was to alert people so that no one would be allowed to claim ignorance either for the purpose of the visit or for the duty to submit to the requirements contained in the edict that incited residents to perform various statements or even reports with less incisive intentions.

It was in this context that, on August 20, 1759, in the parish of Nossa Senhora da Conceicao do Mato Dentro, a district of Serro Frio, the Captaincy of Minas Gerais, that the visitator-general of the Cathedral of Mariana, Jose dos Santos, began a diocesan visitation [21]. In that devasa, 42 free men of white quality attended, including 17 married, 24 unmarried and 1 widower. In fact, the choice of witnesses was part of a veiled strategy of the church to gather the principals of the village to come to the table. Through publicity in a public address at the door of the church and sermons at masses, in addition to the conversations reserved in the act of confession, the priests created a mechanism of control, manipulation and influence in the community.

Concerning the Church's strategies for regulating morals, Foucault comments that after the Council of Trent, countries of strong Catholic influence intensified the rhythm of ecclesiastical precepts. Pastoral care, sermons and confessions were more frequent, and the so-called "crimes of the flesh" and / or "sins of the flesh" came to be more carefully and attentively noticed. Sex became dangerous and therefore needed to be controlled in practice and discourse [22]. The constant vigilance of ecclesiastics began to operate in almost all dimensions of community life.

For the Church, censorship of the "sins of the flesh" functioned as a facet of the counterreformist project, which preached the defense of the values of the Catholic family, based on the sacrament of matrimony. In this sense, the "crimes of the flesh" were sins of a sexual nature which also attacked Christian family morality: incest, adultery, bigamy, concubinage, molycema, sodomy, bestiality, pimping, debauchery, kidnapping, kidnapping and rape [23].

The vast majority of whistleblowers were individuals from Portugal, the Atlantic islands and the various regions of Portuguese America and practiced well diversified economic activities. In this locality, 14 worked in their fields, 8 took the subsistence of mining, 8 lived as businessmen, 3 worked as cobblers, 2 lived the art of surgery, 2 were tailors and with a representative were practitioners of carpentry, apothecary, military, treasurer, convoy and lawyer.

The age pattern of witnesses who revealed age was around 45 years. The group made a total of 142 complaints to the visitor, 99 of them referring to item 17 of the notice that contained 40 questions and referred to people who were living in simple or adulterous amassing. However, there were no specific questions that involved the religiousness of religious, or religious, or indicated the presence of consanguineous incest or affinity. The existence of community standards based on concubinage relations demonstrates how difficult it was to impose a profile that valued monogamy and marriage in many regions of Portuguese America.

There were also complaints about those who promised marriages and cohabited as if they were married. So question 23 asked: "If some are promised to marry and cohabit as if they were received in the face of the Church," come and tell the visitor [24]. Following the tradition of interrogation, in 1737, the Portuguese José de Oliveira and Luiz Ferreira, residents of Contagem, said that an Amaro da Cruz, a native of Samambaia, had long preached to marry a Red named 
Thereza Gonçalves to which they witnesses have seen 'and are received' [25].

The mistreatment of women and their abandonment of their companions, or vice versa, as well as separations without just cause, were also opposed, as shown in question 19 asked by the bureau: "If there is a married man who gives his wife a bad life with scandal or live apart without just cause" [26]. The question was answered by the Portuguese witness André Nunes de Carvalho, who said that João Simões was married to Rita Rodrigues, from the parish of Santo Antônio do Rio Acima, and "they live both separated from each other" [27]. But he, he testifies, "does not know which one is the cause of the end." Thus, too, Anacleto, in the opinion of the visitors, gives bad life to his wife in Portugal, since he had been in Minas for a long time and without the renewal of his wife's license. In that case, his countryman, Manoel Teixeira da Costa, had made the complaint to the visit table by question 40 , which was open to any alleged crime: "If you know of any public and scandalous sin tell us" [28].

Those who were not accustomed to attend Mass, or even practiced eating habits on Sundays and holy days without a license from religious authorities, were reprimanded. Subjective suspicions were cast that this practice could indicate the exercise of Judaism or idolatries that influenced heretical and evil actions such as witchcraft. Consenting to some situation of not knowing the priests could be dangerous. Batuques, gatherings of people in taverns, private houses or vacant spaces were associated with the most diverse moral deviations, mainly to the crime of having alcouce (brothel).

Among the 42 witnesses who appeared before the visitor was Anacleto Pereira Carneiro, who presented himself as a white man, "married natural of the Parish of Fountoura, Archbishopric of Braga who lives of his office of Tailor and of age of fifty years" (sic) [29] following the standard procedure, from which the witnesses were qualified according to the name, quality, social status, residence, naturalness, profession and age. After completing these procedures, it was necessary to verify whether they knew of the debauchery and if they were aware of any crime mentioned in the 40 questions, which were read and declared in the presence of the clerk, secretary and visitor.

Anacleto's interrogation followed the standard ritual of swearing with his right hand over the Bible before giving his testimony. The "Reverend Doctor Visitor General gave the oaths of the holy gospels in a book, which put his right hand on him and promised to speak the truth in what he was asked." It did not take long and Anacleto revealed that:

"João Rodrigues was traveling with Luzia de Araujo, black forra, and more said that it is still evident that Domingos Alves, a blacksmith, was treated with Dorothea de Carvalhaes, who was black, but he did not say and signed with the Reverend Doctor Visitor I Jose Soares Araujo Coat of arms secretary of the visit that I wrote it" [30].

The denunciations made by Anacleto relate to item 17 of the edict: "If any ecclesiastical person, or secular, single or married, that are concubinage with scandal and of that there is fame in the parish, place, country or village or in the greater part of the neighborhood and street tell me" [31]. The testimony of the complainant was sufficient to establish the guilt, since the process of debauchery did not exceed the stage of instruction. The sentence was summary and the accused did not even have the right of defense. After all, for the Church, only knowledge of the act represented the publicity necessary for the definition of guilt. The two couples denounced by Anacleto had no way of escaping from the repressive action of the visitor and acknowledged their mixed relationships. They were admonished in the first lapse of concubinage and sentenced to pay a pecuniary fine.

The ecclesiastical visits in Minas Gerais punished the concubines denounced for the first time with a fine of three thousand reis each; if they returned, the fine doubled and, in the third lapse, amounted to nine thousand reis. From the fourth time, the penalty could have been one of excommunication or imprisonment. In relation to these rates, they could be paid in réis or with current gold, by means of gold octaves, corresponding to the first lap with two, four or six respectively. They also used to vary from region to region.

The most interesting is that Anacleto Pereira Carneiro, in previous misfortune, was denounced for living without leave of his wife who was in Portugal. Victimized by the denunciation of his colleague and rival of profession, tailor and tissue clerk, Manoel Teixeira da Costa, his situation reached the ears of the feared visitor Miguel de Carvalho Almeida Mattos, trained in the sacred canons of the University of Coimbra. In 1748, the visitor was enraged, wanted to send him to the kingdom to make life marital, because the same Anacleto was lost with women in the parish of Santo Antônio do Bom Retiro da Roça Grande. At that time, his executioner was the countryman of the same region, Manoel Pereira Pinto, also a clerk [32].

If this were not enough, the Portuguese clerk Antonio Soares Camelo, made worse the situation of Anacleto, because it revealed that he lived in the adulterous concubine "with a married woman, by name Josefa da Silva Barbosa, and that this knows him for being public fame, but also that she has children in Taboarasu" [33]. Although he had family on both sides of the Atlantic, Anacleto used the strategy of living in concubinage, as many married Portuguese in his homeland did. The fact that she did not marry and choose to live in concubinage with her second mate, of whom she had children, may have saved her life. After all, a second marriage of Anacleto with his first wife still alive would cause the crime of bigamy. In this case, he would be typified by the authorities in item 6 of the edict: "If any man is married to two living women or women with two husbands, even if these are not fame." It was a serious situation that did not need public fame, an accusation was enough to begin a complex process that could lead to his death by the Inquisition. Bigamy constituted a serious affront to Catholic doctrine Tridentine, because it put in check the sacrament of marriage or its overvaluation [34]. Probably the dreaded 
Mattos would not hesitate, he would consign him to the knapsacks of the Holy Office. In this case, the radicalization of the process with various testimonies and practices of torture was a situation that Anacleto would certainly live.

Most surprising is that the allegations involving Anacleto came from a group of clerks, one of them including a tailor, who probably traded fabrics. It is possible to induce, as a probability, that the rivals of the same branch of trade could be in conflict by the market of performance in the village or even by virtue of some disagreement of values in relation to the payment of the purchase and sale of fabrics for the activity of tailoring. Also jealousy and envy were not discarded from this universe of disputes.

We do not know for sure, what led that group to denounce Anacleto's private life, but we know that the debaucheries reflected local and intercontinental power relations, as they were used in disputes by rival groups, who were associated in extensive networks of contacts [35]. In spite of being a joint conceived by the clerks, everything seems to believe that Anacleto actually lived that situation. The visits were repressive, but had their mechanism of protection against those who swore false or even intimidated witnesses. Item 11 of the edict referred to the commitment to truth from the point of view of Christian morality: "If there is any person who swear falsely in judgment, or is accursed or accustomed to swore false and scandalous oaths outside the Judgment," [36] he could incur crime of perjury.

Item 38 was more incisive in the defense of the procedure of demarcation, since it protected the witnesses, as is evident in the question: "If you know or have heard that someone intimidated witnesses, that they came or were to come to visitation not to say truth, or after they had witnessed that they had dealt ill with words and deeds" [37].

Anacleto Pereira Carneiro, victim of the complaints of the clerks, ended up being sentenced on the two days of October 1748 , being obliged by the visitor not to go to the house of Josefa da Silva Barbosa anymore. Complementing the term, Mattos asked Anacleto not to talk to Josefa in public or in secret, nor to send her presents, gifts or messages [38]. In the report drawn up by the secretary of the visit, only his concubinage with a married woman appeared. The name of Josefa was hidden, because this publicity could bring you bigger complications with your husband. The revelation revealed that she had even adulterous children fruit of her relationship with Anacleto [39]. Then the visitor Mattos following the publicity procedures assigned to the secretary that:

(...) soon take to published the guilts of the errands outside the season of masses and their customers and after published the fara ires plowing paper separately that will set in public place of this Church where they will be read and served will take away while the visitation lasts of its parish and not of certain of this pass certain of fame of the list that take in all (...) $[40]$

Just as the pedagogical function of the amendment was the valorization and defense of marriage by the ecclesiastics, Josefa was preserved, for the publication of her name might not have the effect desired by the priests. This seems to have been a common strategy for priests in relation to married women. In Sabará, for example, Luzia Fortuna was living in a relationship with her compadre. Condemned by the crime of adultery and incest, she asked the visitor to consider what she should do in relation to publicity in the role of release, since, "considering that she was a married woman, and had a fair fear that her husband would be aware of the said crime, by which he could work the most holy surplus" [41] (sic). Certainly to remain anonymous would save his life and keep the marriage. The fact is that married women in repentance before the visitors were preserved. Therefore, in the list of released from the village the name of Josefa would remain anonymous. Anacleto's account was revealed as the secretary of the visit determined to sign the blame for the first time, according to the document transcribed below:

"On the two days of October of one thousand seven hundred and forty-eight years in this camp of Santa Luzia in Casa where the Reverend Doctor Visitor Miguel de Carvalho Almeida Mattos was found, with me Secretary Below named, being there appeared Anacleto Pereira Carneiro, notified his order for the satisfaction of the guilt that resulted from the devastation of the visit of this same Parish to which the said Lord admonished in the form of the Tridentine Council, so that at all it would be separated from the illicit communication that it has with a married woman and no more let his house neither speak in public nor in secret, nor send him gifts or errands, and thus make the whole scandal of his sin cease, considering the very grievous offenses which he does to the Lord God in the continuation of him with manifest danger to which they expose their salvation persevering in such a miserable state; with condemnation of being with the greatest severity punished and censored. He accepted the admonition and made the guilty verdict and promised amendment. And it was condemned in four octaves that he made this term with the visiting doctor; And I, Father Francisco Almeida Barbosa Secretary of the Visit, who wrote it [42].

This document marks the final juridical procedure of an ecclesiastical devassa. The drafting of the condemnatory term of Anacleto Pereira Carneiro reveals the richness and complexity of a source that is subdivided into three distinct categories: edital; testimony and interrogation; pronunciations and drafting of the term of guilty parties.

The records of ecclesiastical devassas are divided into two parts: the list of witnesses (which includes the edicts, pronouncements and denunciations made by the population, due to the inquiries made by the visiting padre) and the list of sentenced persons (containing the drafting of guilts or deliverance). Anacleto, at different times, figured in every phase of the process. These two lists, for the most part, were separated, since the visiting table generally performed the procedures of the debauchery and the visitations in different periods. At first, he collected testimonies and, some time later, brought the guilty parties and applied the penalties [43].

The fact is that Anacleto created disagreements and his family situation came to public motivated by the rival group, 
which would eventually result in his escape from that parish of Roça Grande, in the District of Rio das Velhas. This seems to have happened, because 12 years later, in the parish of Mato Dentro, in the region of Serro Frio, the same Anacleto had established a house. In fact, he was no longer on the list of guilty men, even though he had not returned to the arms of his wife, still alive, in Portugal. Stabilized with the local power networks, Anacleto did not appear as a victim and acquired respect, as he participated as a witness and denounced the concubinage involving Portuguese couples with Africans.

Ramos, in a study of the 40 questions related to inquisitorial processes, demonstrated how the Church used the public and notorious expressions to legitimize its action by the clamor of an alleged "popular voice" [44]. In his article, Ramos makes a preliminary effort to try to trace the contours of a dominant culture and popular or alternative culture. His study throws light, but it is an introductory study of the relation of disputes and influences between cultures. Ramos will use Ginzburg to say that the popular voice was a filter through which values of both cultures were transmitted and thus transformed. The question is who and what social groups influenced such cultures? The problem is to define which agents have given meaning to popular or alternative culture and elite culture, learned, learned or dominant. In this aspect it is increasingly necessary to relate these forms of culture to social groups in the temporal perspective, for only then will we clearly observe such influences, which have not been lost by the process of imbrication in time.

Witnesses were key pieces in the process of visitation. To legitimize the whole framework of vigilance, it was necessary for a certain group of people to conform to the action of the ecclesiastics. The descriptions of daily life that revealed the "deviations contained in the edict questions were presented by the following witnessing expressions:" knows by being close, "" knowing by seeing and witnessing "or by expressions that pointed to the collective as an alibi, "Knows for being public fame" or "knows for being public and notorious". These last expressions guaranteed the witnesses an attitude of detachment and security accompanied by the collective. Usually, the witness group was restricted to the Portuguese. If among them there existed a regularity of men with condition of free and of white quality, between those who were victims of the denunciations this homogeneity is lost. Among the denounced in the parish of Mato Dentro the division was almost equal in relation to the sex of the individuals. After all, 103 were reported men and 100 women.

The social condition of the accused reflects a better division in relation to the whistleblowers, the free individuals are the majority, followed by the freedmen and the slaves. The quality of the individuals denounced was very diverse: 104 whites, 40 blacks, 22 blacks, 19 browns, 7 mestizos, 6 . mulattoes, 4 goats and 1 Indian carijó.

In a way, the choice of witnesses among the group of white men for the denunciations, mostly Portuguese, reflects, a cultural homogenization of those who already had contact with the edict and the logic of the devasas. This homogenization marks the inequality of race and gender among that group of witnesses who dominated the denunciations. However, the people who appeared as denounced reflected a contrary, heterogenic and diversified logic, since it included people of different qualities and social groups.

\section{The Edict of the Debauchery and the Morphology of the Denunciations, a Logic in Reverse}

The edict of the visit was, in fact, a copy of the Regiment of the Ecclesiastical Auditorium, which regulated the whole procedure of the debauchery to be made. In some cases, the edital was modified to better accommodate the need of the visitor and the place that would undergo surveillance. The procedural structures observed in the evicts' edicts project to distant realities, a long mental temporality. However, this temporality is not static, at the same time, when it imposes a tradition, it also undergoes influences and modifications of those places in which they were applied. In this sense, the edicts of the devasas, even though they have a universal procedural structure, which refer us back to the Middle Ages, are also bearers of many temporalities, since procedural logic is inserted in temporal and spatial realities.

In Portuguese America, the procedure for the visitation of the devastate was only regulated in 1720 , precisely by the creation of the Regiment of the Ecclesiastical Auditorium, which was a more practical compilation of the doctrinal rules of the First Constitutions of the Archbishopric of Bahia, 1707. creation defined what was meant by pastoral and ecclesiastical devastation, separating nature from the purpose of the two actions.

In fact, diocesan devasas or diocesan visits differed from letters and pastoral visits, which had a more pedagogical and enjoyable, but no less active, function. Although they had little differentiation in the action performed by the bishop, the two procedures constituted a complement to each other. Through a pastoral action one could institute an ecclesiastical debauchery and vice versa. In any case, this decision was in the character of the person in charge of the diocese, who was the bishop.

The initial act of operation of the visit was the transfer, in the proper book, of the three provisions of appointment and edict. The edict of the visit was aimed at vicars, priests, coadjutors, cured chaplains, other civil and ecclesiastical authorities and the population of the parish to be visited. In these documents, the solemn objectives of the visit were declared, to "banish the vices, errors, abuses and scandals" of the residents and to watch over Christian behavior in the spiritual and temporal question.

The text contained in the edict was read by the clergy and local secular and ecclesiastical authorities, who were in charge of notifying the arrival of the visitor in each of the Churches, so that, on those occasions, people would attend 
the procession for the salvation of souls of the dead, which always took place before the devassa began.

The edict contained the main guidelines that should be followed. The visit of 1748, in the region of Serro frio and the Rio das Velhas, was thus revealed:

"Notice

Dr. Miguel de Carvalho Almeida Matos Vicar of the Vara and Judge of weddings, residues and chapels of the Region of Serro Frio, ordinary visitor of this visit of devastation in the Region of Pitangui and Sabará and more Parishes, by the most Reverend Monsieur Frei Manuel da Cruz Master Retired in Sacred Theology, Doctor of the University of Coimbra First Bishop of this new bishopric of Mariana and of the council of His Majesty. All the people related to the ecclesiastics, as secular of the above-mentioned Counties and Parishes, health and peace in Jesus Christ our true Lord, who is a true remedy and salvation, you must take into account the said Visitor that with the diocesan Visitation horrible scandals and peace becomes very salutary. From this consents to the spiritual and temporal good of these subjects, I was sent to make visits to the visit of the District and the Pitangui and Sabará and other Parishes outside that do it as is convenient Secular services. In the spiritual good of the above-mentioned, I command in versu of disobedience and under penalty of excommunication many attitudes of the people and each one to praise of the work wisdom, or public fame of some public sins with scandals, and in the special cases, that below declare in a term of eight days that the denunciation shall come to me, and I admonish and exhort all Isma Sisters, that for the denunciation of said sins to move faithfully with jealousy, and the Love of the service of God our Lord, and the salvation of their neighbors and not with hatred or desire of revenge, and so that they know the sins of which they must denounce them, I hereby declare in this edict by the following way (...). (...) 40 And finally we know of any public and scandalous sin to tell us. And the fears people, holy parish priests that you gave bad and say that this is not the state of this first. Clerics of days Saints soon lead to published the guilts of the errands were in the season of the masses and their customers and after published the were to draw in paper apart that they fixed in public place of this Church where it passes to be read and serve will take during the visitation of the his parish and not certain of this passed certificate of fame of the list to carry throughout the past in this Village of the Prince on July 7, 1748 with Mr. Francisco Alvares Barboza secretary of the visit that I wrote" [45].

Through the application of edicts like this in the communities visited by ecclesiastics the population reported the customs that were practiced. Some of these reports were intended for denunciations, others were not. However, this depended on the degree of knowledge of Christian doctrine that the individual called at the table of the visit was bearer. However, the ecclesiastics in applying these questions to the patrons acquired information to confront daily practice with the principles of Tridentine morality. It was from this information that the bishops established, in Minas Gerais, in the eighteenth century, the strategies for moralizing customs.

\section{Conclusion}

The systems of action of the ecclesiastical tribunals in the Spanish and Portuguese Americas resembled and created a broad landscape of action by the Catholic Church in the New World, especially after the unification of the Kingdoms of Spain and Portugal with Philip II. Thus it is possible to understand how different popular customs integrated into the legal universe that proposed a globalizing Christianity. In the case of documentation produced by the ecclesiastical court, specifically, the records of ecclesiastical devasas the logic demonstrated seems to operate. For this documentation allows us to trace a panorama of the colonial daily life through the details of the so-called "crimes of customs", that is, of the sins committed by the population according to the Tridentine Church. These documents were drawn up with the intention of imputing sentences to people who lived in disagreement with Catholic morality. They had an inquiring nature, in order to warn and punish the "deviants of the faith". They are, therefore, an excellent source for the study of political and institutional history, as well as of social history and culture, since they allow us to visualize the daily behavior of the population in questions not only religious, but customs. In the analysis of this documentation, it is possible to apprehend questions concerning the family life of the social groups regarding love, affection and sexuality.

\section{References}

[1] A. W. Novinsky, Prisioneiros do Brasil-séculos XVI a XIX. 2 ed., São Paulo, Perspectiva, 2009; L. Mott, Rosa Egipcíaca: uma Santa Africana no Brasil, Rio de Janeiro, Bertrand, 1993; R. Vainfas, A heresia dos índios, São Paulo, Cia das Letras, 1997.

[2] J. Le Goff, Para um novo conceito de Idade Média: tempo, trabalho e cultura no ocidente, Lisboa, Editorial Estampa, 1993 , p. 9-16.

[3] J. Traslosheros, Es Iglesia, justicia y sociedad en la Nueva España. La audiencia del arzobispado de México, 1528-1668. México, Porrúa, Universidad Iberoamericana, 2004.

[4] S. Gruzinski, "Les mondes mêlés de la monarchie catholique et autres 'connected histories", Annales Histoire, Sciences Sociales, n. 1, Paris, 2001, p. 85-117.

[5] L. R. de A. Figueiredo. Barrocas Famílias: vida familiar em Minas Gerais no século XVIII, São Paulo, Hucitec, 1997.

[6] R. Vainfas, Trópico dos pecados: moral, sexualidade e inquisição no Brasil colonial, Rio de Janeiro, Campus, 1989; A. H. Twinam. Sexuality, and Illegitimacy in Colonial Spanish America. In: LAVRIN, Assunción. Sexuality \& marriage in colonial Latin América. Nebraska: University of Nebraska Press, 1989.

[7] F. T. Londoño. A outra família: concubinato, Igreja e escândalo na Colônia, São Paulo, Loyola, 1999; R. C. Netto, Um em casa do Outro: Concubinato, família e Mestiçagem na Comarca do Rio das Velhas (1720-1780). São Paulo, Anablume, 2008. 
[8] C. C. Boschi, "As visitas diocesanas e a inquisição na Colônia", Revista brasileira de história, v. 7 (14): 151-184, São Paulo, mar./ago. de 1987.

[9] D. de Vasconcellos, História do Bispado de Mariana, Belo Horizonte, Biblioteca Mineira de Cultura, 1935, p. 46-47.

[10] E. Nobert, O Processo Civilizador 2. Formação do Estado e Civilização, Trad. Ruy Jungmann, Rio de Janeiro, Jorge Zahar, 1993.

[11] J. F. Carrato, A crise dos costumes nas Minas Gerais do século XVIII, Revista de Letras, v. 3. São Paulo FFLA, 1962, p. 216-248.

[12] L. de M. e Souza, Desclassificados do Ouro: a pobreza mineira no século XVIII, Rio de Janeiro, Edições Graal, 2004, p. 9-15.

[13] C. Ginzburg. O inquisidor como antropólogo: uma analogia e as suas implicações, A micro-história e outros ensaios, trad. António Narino, Lisboa, Difel, 1989, p. 203-214.

[14] C. Ginzburg. História Noturna: decifrando o sabá, Trad. Nilson Moulin Louzada, São Paulo, Cia das Letras, 1991.

[15] A. Farge, Le goût de l'archive, Seuil, 1989, p. 147-148.

[16] R. Chartier, A História cultural. Entre práticas e representações, Rio de Janeiro, Difel/Bertrand do Brasil, 1991, p. $120-121$.

[17] S. B. Schwartz, All Can Be Saved: Religious Tolerance and Salvation in the Iberian Atlantic World, New York and London, Yale University Press, 2008.

[18] M. L. C. de Resende, Devassa da Vida privada dos índios coloniais nas vilas de El Rei, Estudos Ibero-Americanos, v. XXX, n. 2, Porto Alegre, 2004, p. 49-66.

[19] Constitutions of the Archbishopric of Bahia, liv. 5, t. XXXIV, 1707, p. 1056-106.

[20] C. S. Lemos, A justiça local: os juízes ordinários e as devassas da Comarca de Vila Rica 1750-1808, 2003. 178 p. Dissertação (Mestrado em História). Belo Horizonte. 2003, p. 91-94.

[21] Archives of the Archdiocese of Mariana, Devassas, Liv. Witnesses, August-January, 1759, f. 32.

[22] M. Foucault, The History of Sexuality Volume 1: An Introduction. London: Allen Lane., 1976, p. 22-24.

[23] Constitutions of the Archbishopric of Bahia, liv. 5, t. XVI, 1853 , p. 331-355

[24] Archives of the Archdiocese of Mariana, Devassas, Liv. Witnesses, July-January, 1748-1749, f. 5.

[25] Archives of the Archdiocese of Mariana, Devassas, Liv. Witnesses, June-September, 1737-1738, fs. 62, 62v.

[26] Archives of the Archdiocese of Mariana, Devassas, Liv. Witnesses, July-January, 1748-1749, f. 5.
[27] Archives of the Archdiocese of Mariana, Devassas, Liv. Witnesses, June-September, 1737-1738, f. 177.

[28] Archives of the Archdiocese of Mariana, Devassas, Liv. Witnesses, July-January, 1748-1749, f. 6.

[29] Archives of the Archdiocese of Mariana, Devassas, Liv. Witnesses, August-January, 1759, f. 40.

[30] Archives of the Archdiocese of Mariana, Devassas, Liv. Witnesses, August-January, 1759, f. 40-41.

[31] Archives of the Archdiocese of Mariana, Devassas, Liv. Witnesses, July-January, 1748-1749, f. 4v.

[32] Archives of the Archdiocese of Mariana, Devassas, Liv. Witnesses, June-April, 1748-1749, fs. 57, 58v, 59.

[33] Archives of the Archdiocese of Mariana, Devassas, Liv. Witnesses, June-April, 1748-1749, f. 60v.

[34] S. M. J. Brugger, Minas Patriarcal: família e sociedade (São João Del Rei - séculos XVIII e XIX), São Paulo, Annablume, 2007, p. 65-131.

[35] R. C. Netto, E. F. Paiva, Uma mamaluca poderosa entre Itu e Pitangui no início do século XVIII. In: Leandro Catão. (Org) Pitangui Colonial. Crisálida/Arquivo de Pitangui, 2011, p. 133-154.

[36] Archives of the Archdiocese of Mariana, Devassas, Liv. Witnesses, July-January, 1748-1749, f. 4.

[37] Archives of the Archdiocese of Mariana, Devassas, Liv. Witnesses, July-January, 1748-1749, f. 14v.

[38] Archives of the Archdiocese of Mariana, Devassas, Liv. Witnesses, June-April, 1748-1749, f. 64.

[39] Archives of the Archdiocese of Mariana, Devassas, Liv. Guilty, July-January, 1748-1750, f. 28v.

[40] Archives of the Archdiocese of Mariana, Devassas, Liv. Witnesses, July-January, 1748-1749, f. 6.

[41] Archives of the Archdiocese of Mariana, Devassas, Liv. Guilty, December-September, 1733-1734, 1. 2. f. 84.

[42] Archives of the Archdiocese of Mariana, Devassas, Liv. Guilty, July-January, 1748-1750, f. 2, 28v.

[43] R. C. Netto. Entre as formas de se pensar e as maneiras de se viver: a família Mestiça e a vida familiar em Minas Gerais colonial. São Paulo, Alameda, 2017.

[44] Donald Ramos. The "popular voice" and popular culture in eighteenth-century Brazil. In: Maria Nizza da Silva (org), Portuguese Culture in the Land of Santa Cruz, Lisbon, Estampa, 1995, p. 137-154.

[45] Archives of the Archdiocese of Mariana, Devassas, Liv. Witnesses, July-January, 1748-1749, f. 3v. 